\title{
Philosophy of Allama Iqbal with special reference to the Islamic society and Culture
}

\author{
Mohd Rafi Paray ${ }^{1 *}$, Hiralal Fulware ${ }^{2}$
}

${ }^{1}$ Research Scholar, Devi Ahilya University Indore, MP, India. ${ }^{2}$ HOD Department of Sociology, Dhar College Indore, MP, India.

\begin{abstract}
A Philosophy is a discipline of facts and knowledge undoubtedly relevant to the coming into being of all facets of human life. As it sheds light on the issue of life and human fate, knowledge is inferred and postulated. Allama Muhammad Iqbal made an invaluable contribution to the provision and solution of Islamic society's problems. The article is an attempt to examine Allama Iqbal and his contribution to social theory. This is based on a study of relevant literature, with a focus on conceptualizing Iqbal and his contribution to Islamic culture and society. It is precisely this unity of culture and faith that will form the basis for the views of Muhammad Iqbal on Muslim culture. The most critical aspect of social life and the cornerstone of its transition is the culture of the Iqbal view. He thought that culture plays a greater role in clarifying social change than other variables, such as economics and politics. Though Iqbal has studied Western thought extensively, the views of Iqbal on culture are basically influenced by the teachings of the Qur'an and Hadith. This paper seeks to discover the idea of Muslim culture and society of Iqbal, and the fundamental principles that empower, encourage, and guide Muslims in their cultural pursuits.
\end{abstract}

Key words: Human destiny, Islamic society, Muslim culture, Social life, Social change, Culture pursuits etc.

\section{INTRODUCTION}

In the early twentieth century, Allama Muhammad Iqbal (1877-1938) was an Islamic scholar and poet. He had a reflective view of the Prophet Muhammad's Holy Quran and Sunnah and had extensively investigated Western thought. He was armed with strong access to the origins of both Islam and Western modernism through his Islamic understanding, education and his study of philosophy in the West. Thus, his approach to Islam is broader than that of conventional theologians and educated Muslims from the West.

\section{Allama Iqbal's View of Islamic culture \\ Islamic culture applies to cultural rituals common to the people of Islam. The definition of}

Islamic culture by Iqbal is not limited to religious, geographical, and national constraints; rather it encompasses a very broad spectrum and comprises all expressions of human activity. For Iqbal, the concept of self, the concept of society, and the concept of life as a continuous movement in time are defined comprehensively by Muslim culture. All of these principles are inseparable and directly conducive to his views on Muslim culture $(1,2)$.

The theory of self is the most fundamental feature of the views of Iqbal on Islamic culture. In the works of Iqbal in Persian, Asrar-i-khudi and Rumuz-i-bekhudi, this theory of self has been identified. Asrar-i-khudi, under the title Secrets of the Self, was translated into English by Professor R. A. Nicholson of

*Address of Correspondence: Mohd Rafi Paray, Research Scholar, Devi Ahilya University Indore, MP, India, India. E-mail- raafay198@gmail.com

(Received 24 December 2020; Revised 08 January 2021; Accepted 14 January 2021) 
Cambridge University. This deals with the philosophy of self, or the personality of the individual. Meanwhile, Professor A. J. Arberry translated Rumuz-i-bekhudi into English under the title The Mysteries of Selflessness, and it deals with the man in relation to his society (3).

Iqbal also stressed in his definition of Islamic culture the essential relationship between the spiritual and the material aspects of the life of man. The metaphysical and material elements are not two competing forces for him and the affirmation of the spiritual self-calls for a ready embrace of the material world in order to make it an ally in our creation process. It is only because of the inseparable bond that man has been able to sharpen his intellect and create a great culture and civilization between the two. In defining human life, Iqbal often used two significant terms; Alam-i Anfus (spiritual world) and Alam-i Afaq (material world). He blamed both the extreme materialists and the extreme idealists who reject the reality of Alam-i Afaq for denying the reality of Alam-i Anfus. He assigned equal value to both man's existence and development, and so to Muslim culture and society, and rejected the idea of one's superiority over the other (4).

The definition of community is another significant component of Muslim culture. The human self, according to Iqbal, has a larger self and that is the society to which it belongs. Iqbal argued that society is a must for human self to grow and develop properly and that man can achieve self-realization and fulfil his missions only in society. Therefore, Iqbal has given an equal importance to the individual and society in cultural developments. A lasting human civilization was formed by the harmonious work of the individual and society. In their shared struggle to create a successful society, both complement and supplement each other. In other words, the person is the inner and the external representation of human culture is society. For Iqbal, there is a necessary link between the individual and society, and both contribute to the growth of each other. Society encourages the individual to control himself and to realise the best in him, while the person supports cultural growth in society. Iqbal explored the role of society in his book, Rumuz-
i-Bekhudi, and addressed the relationship between the individual and cultural life of the society in which he works, moves and lives. "He said He is frail and helpless alone, his energy is dispersed and his mind is narrow, diffuse and indefinite. It is the active and living membership of a critical society that gives him a sense of control and makes him aware of great common ambitions that deepen and extend the potential for the advancement of his individual self.

Iqbal recognised that attachment to a society is a blessing for the individual because it is in society that people grow their personalities and achieve their perfection. He believed that people are fundamental units of society, and through individuals, society is formed and organised.

The conception of society by Iqbal is not limited and parochial. It is not racial or geographical unity which can form the right basis of people's coherence; rather it is the unity of beliefs and purposes which unite a collection of individuals into a genuine human society. Human culture and civilization is thus a matter of both the ideology inspiring individual and societal conduct and social environment provided for its development. The ideology which inspires both the individual and the society is to be found in the framework provided by religion. Therefore, Iqbal looked at the function of religion in the life of the individual and the society, which gives birth to human culture and civilization. It is in this sense that religion is an integral and inseparable part of human culture and civilization.

Some basic conditions for an ideal Muslim society were laid down by Iqbal. The most significant criterion is that the belief in Tawhid must be centred on it. For him, tawhid is the soul of society because it generates unity of thought and unity of actions in individuals who are bound together by society. The second important corner-stone for the structure of the ideal Muslim society is faith in Prophethood. Iqbal emphasized that the strength and the unity of the Muslim society are based on the adherence to the Qur'an and the practice of the Prophet (p.b.u.h) or Sunnah. Thirdly, Muslim society should abide by the code of law, that is, 
shari'ah. Iqbal identified Muslims" failure to abide by the shari'ah as the primary cause for their decline. Besides a code of law, an ideal society also needs a common centre for all its cultural and social activities. Iqbal emphasized that the unity of a society emanates from this very centre, and its existence can become strong by the strength of this centre. For the Muslims, this centre is provided by the kaabah in Mekah. It helps in maintaining unity of the Muslims and promotes their integration as religious community through a pilgrimage assembly once in a year. The next requirement for an ideal society is that it must have a goal towards which the whole community should strive. For Muslims, the objective is the preservation and propagation of the principle of tawhid. Furthermore, the Muslim society must acquire mastery over the study of science. In fact, Iqbal mentioned another reason for the decadence of Muslims nation is the neglect of science. Last but not least, Iqbal gave emphasis on the importance of safeguarding maternity for the sake of preservation of society $(5,6)$.

Iqbal considers the basis of Muslim Ummah in the adherence to Prophet Muhammad by stating: "The essential difference between the Muslim community and other communities of the world consists in our peculiar conception of nationality. It is not the unity of language or country or the identity of economic interest that constitutes the basic principle of our nationality. It is because we all believe in a certain view of the universe, and participate in the same historical tradition that we are members of the society founded by the Prophet of Islam. Islam abhors all material limitations, and bases its nationality on a purely abstract idea, objectified in a potentially expansive group of concrete personalities. It is not dependent for its life principle on the character and genuine of a particular people, in its essence it is nontemporal, non-spatial".

\section{Spirit of culture}

Muslim culture promises change and development in the entire life of man under the leadership of the Prophet (p.b.u.h) and the guidance of the Quran. Religion as a cultural power is mostly functional and realistic for Iqbal. $\mathrm{He}$ pragmatically addressed the importance of religious experience in order to judge it. For him as opposed to mystic experience, the religious experience of the Prophet has social meaning. As an active agent of social reform, the Prophet (p.b.u.h) returns to normalcy and causes the powers of life to be guided and the ends and aims of human and public lives to be reshaped. The spiritual experience, meanwhile is assumed to be an end in itself and so its return to normalcy is meaningless for human society. It ends up in his personal successes, but does not mean much to the whole of humanity. The Prophet's religious experience, however is intended to fully change the human world. By citing a new value system, the Prophet (p.b.u.h) is supposed to provide a new path to society so that he can drag society out of stagnation. In this way, the return from such an experience is imaginative. For Iqbal, without the word of the Prophet Hood, the perfection of human society is unlikely.

Iqbal clarified the role of the Prophet (p.b.u.h) in the creation of a civilised society in this respect. He argued that the greatest human personality was the Prophet Muhammad (p.b.u.h); he was a great state builder and constitutional legislator. Thus in relation to real culture and society, the Prophet (p.b.u.h) was regarded as the greatest reformer and leader in human history. The Prophet (p.b.u.h) left a great spiritual legacy over many centuries that guided human society. In the past, the legacy of the Prophet (p.b.u.h) had such a great influence and would have a greater impact in the future precisely because he founded the religion of truth and laid the foundation for the only society that guaranteed man's happiness and happiness. Therefore the religion which the Prophet (p.b.u.h) transmitted and the culture, which he founded at his Allah's command, are inseparable from each other. In reality, according to Iqbal, the purpose of religion was to build up a true civilization and he argued that a civilization only deserves to be called a true civilization if it can present its pure state to Islam as a religion.

\section{Iqbal's Philosophy of Self}

In all Iqbal's poetic works, the philosophy of self was subsequently created, and more self is essential for the understanding of the nature of culture and the concept of its development. 
Iqbal found himself to be the basis of life's entire organisation. According to him, self is an active and creative force through which a person should aspire to attain a refined personality and participate in the affairs of the universe in order to suit his highest role as God's vicegerent on earth. Self is often known as the centre of the operations and acts of all citizens. Iqbal therefore dismissed all philosophical and theological schools of thought that inculcated self-denial or self-abandonment and denied selfreality, and considered it to be a mere delusion that was not worth striving for. Weakness, laziness and inaction are considered interesting things by the idea of self-negation, and it includes a renunciation of the universe, freedom from the struggle of life and existence in asceticism. Obviously, they are against the spirit of Islam. Iqbal is also firmly opposed to the selfnegation theory, and he noted that this notion was the primary cause of the Muslim nation's decline. According to Iqbal, the spiritual and religious ideal of man is not self-negation, but it has to be self-assertion or self-realization. Since man is God's supreme creation, for the perfection of his own personality and for the advancement of society, he must realise his intrinsic capacity, power and possibilities.

According to Iqbal, the rise or fall of people and nations is due to their selfreinforcement or weakening. If people or nations turn their attention to the realisation and recognition of themselves, they will become powerful and will live in power and grandeur. In the meantime if they deny themselves, they will become weak. Therefore, man should improve and carry himself to perfection; he should play an active role, act and respond to his environment intentionally. In this context, Iqbal believed that it communicates with its material and cultural environment and uses it to understand the purpose of the life of man as both a servant and God's vicegerent. Iqbal obviously emphasised the active existence of self-development.

Speaking of self-development, Iqbal stressed the notion of independence. According to him, freedom of oneself is not absolute in its form; rather it is subject to God's duty and accountability. Under the teachings of Islam, as a holistic code of life, the inner desire for liberation must be regulated and directed by God. Therefore, Iqbal saw self-activity as a directive energy by which man is free to act under the guidance of God in this universe. For him, liberty means that man is able to free himself from his whims and to transform to God. Iqbal found obedience and love for God in this regard to be the primary requirement for the proper development of oneself, and that is the early stage of self-development. According to Iqbal, the last stage of self-development is the viceroyalty of man. It is the stage where man played an active role on earth as God's vicegerent and would turn the world in accordance with the values set forth by the teachings of Islam.

Iqbal was a powerful religious believer without whom the social system could not operate properly. That is why the rebirth of Islam and the preservation of Islamic society were the subject of his efforts. He felt Islam was the most important contribution to world thinking. Islamic society, such as the unity of God, the finality of Prophethood, the sharia't, the Islamic Code of Law and Akhuwah (Brotherhood), has a permanent feature in its system of thought. To Iqbal, a society's stable character depends directly on the basic respect for the ultimate realities that govern life. It can be said from the above evaluation of the views of Iqbal that Iqbal describes Tawhid, Risalah, and Akhuwah as the basic and fundamental values of the Ummah (Muslim community). For him it would deviate from the real aims if a society deviates from any of these values (7).

\section{METHODOLOGY}

A research study aims to acquire new knowledge and use descriptive methods to find answers to the problem. Descriptive research is research performed on a topic that has been more clearly explored and helps to decide the best research design, method of data collection and subject selection. These were chosen for the study and contribution of the social theory of Allama Iqbal to Islamic society. The secondary source of the data used to achieve the study goals set. Primary data sources obtained from books, magazines, newspapers, magazines, studies released and official sources 


\section{DISCUSSION AND CONCLUSION}

Iqbal was a firm religious believer without whom the social system could not operate properly. That is why he concentrated on the rebirth of Islam and the security of Islamic society in his efforts. He felt that Islam was the most valuable contribution to world thinking. Islamic society, such as the unity of God, the finality of prophecy, the sharia't, the Islamic Code of Law and Akhuwah (Brotherhood), has a permanent feature in its system of thought. The concept of self by Iqbal has been explored since he believed that self-understanding is central to an understanding of the nature of culture and the concept of its development. He is well aware that while it is fundamentally inconsistent with the spirit of Islam, the doctrine of self-negation has crept in and coloured Muslim thought. Iqbal has given us an understanding of the true nature of the self, as opposed to some religious and metaphysical schools of thought that belittled the truth of self and treated it as a mere illusion of mind and not having any lasting significance of their own. For him, self is an object that is true and pre-eminently essential, which is the origin and cornerstone of human life's entire organisation. Iqbal made an effort to interpret the reality of life in terms of human will and behaviour based on his principle of selfassertion or self-realization. Iqbal tried to offer a diverse quality of Muslim thought and action by preaching the fullest affirmation of self in this real world of powers. In addition, Iqbal believes that it is difficult to cultivate an active individuality, even in interaction with a social context. Therefore in the development of Muslim culture, he put equal emphasis on the person and society. Iqbal was well aware of the importance of the culture of a community for the individual's proper growth. On the part of its members, the continuity of a society's cultural life relies on both a sincere respect and a critical evaluation of its cultural values and practises. They must have the capacity to recognise, assimilate and recreate the current community in an active way (8-10).

In addition, in his conversation about the spirit of Muslim culture, Iqbal drew on three sources of knowledge described in the Qur'an; inner experience, nature, and history. According to Iqbal, Muslim thinkers should not appeal to the speculative character of Greek philosophy, which enjoyed theory and ignored truth, to bring out the true spirit of Muslim culture. Muslim culture's spirit is based on the concrete and finite. He deeply believed that the birth of Islam's system of observation and experiment was not due to a compromise with Greek thought, but to a protracted philosophical war with it. Iqbal called this an intellectual rebellion against the philosophy of Greece $(10,11)$.

\section{CONFLICT OF INTEREST}

There is no conflict of interest in this present research paper. This research work is not a part of any other studies and it is our original work.

\section{REFERENCES}

1. Muhammad Iqbal. The Reconstruction of Religious Thought in Islam, London. Oxford University Press. 1934; p. 158.

2. Muhammad I. The Reconstruction of Religious Thought in Islam, Stanford/London: Stanford University Press. 2012; p. 102.

3. Iqbal Dr. Asrar-o-Rumuz, Kutub Khana Naziriya. 1971; pp. 92-93.

4. Chaudhri M.A. Iqbal and Modern Muslim Society. Islamabad: National Institute of Historical and Cultural Research Centre of Excellence. Quaid-i-Azam University. 2005; 27: 45-9.

5. Fay B. Contemporary Philosophy of Social Science: A Multicultural Approach. UK: Blackwell Publishing. 2003; 44: 77-8.

6. Bertrand R. A History of Western Philosophy and Its Connection with Political and Social Circumstances from the Earliest Times to the Present Day. Lahore: Routledge. 1970; p. 173.

7. Ahmad A. The Concept of Self; and Self-Identity in Contemporary Philosophy. Iqbal Academy, Lahore, Pakistan. 1986; 15: 67-7.

8. Al-Attas SMN. The concept of education in Islam: a framework for an Islamic philosophy of education. ABIM, Kuala Lumpur, Malaysia. 1980; 34: 56-8.

9. Ashraf S. A Critical Exposition of Iqbal's Philosophy. Associated Book Agency Patna, p.145

10. Saiyidin KG. Iqbal's Educational Philosophy, 8th ed, Shah Muhammad Ashraf, Lahore. 1977; p. 56.

11. Sherwnai Latif Ahmad. Speeches, Writings and Statements of Iqbal, New Delhi. 2008 p. 121. 